\title{
Economics of Optimizing Value Chain in Agriculture Sector of Nigeria through Mechanised Crop Processing and Marketing
}

Review Article

Nwele, J. Obasi ${ }^{1}$, Ngene, Amuche $\mathrm{N}^{2}$ \& Udeaja, Elias A. ${ }^{3}$

${ }^{1}$ Director of Planning, Research and Development, Centre for Social Education and Human Development, Abbaomege, School of Business Economics and Legal Studies, PRA, No. 78 Ukau Road - Nigeria. ${ }^{2}$ Department of Economics, Renaissance University, Enugu.

${ }^{3}$ Central Bank of Nigeria, Abuja.

Corresponding Author

Author Email:

obasijen@yahoo.com

\section{Contribution/Originality}

This study contributes to the assessment of the existing level of misunderstanding, politics and social problems of the great challenges of approach and management in agriculture value chain through processing, packaging, storage, distribution and/or marketing in Nigeria. This study projects new aggregate level distinction on research matter analysis of agriculture value chain through processing, packaging, storage, distribution and/or marketing in Nigeria. The paper contributes to the first grade logical analysis of new world understanding of the economics of agriculture value chain.

\section{Introduction}

\section{Agriculture and the economics of agriculture value chain}

The agriculture sector is favourable in every society, as it allows greater employment opportunities for the poor. The industrial sector is important for boosting the economy, but has failed to create sufficient employment opportunities for the poor and unskilled workers. Recent happenings and research of this nature has established that African countries could not launch a successful economic transformation without going through an agricultural revolution of a country-wide basis.

Today, fifty-nine years (1960-2019) after gaining independence, Nigeria should compete with major economies of the world rather than just the economies of Africa. Nigeria as a country is rich in natural resources and has identified the fact that taking appropriate measures can speed up its economic development and vision 20-20-20 program came up as a result of this belief. Remember that the earlier visions - (vision 2000, and vision 2010)
Abstract: The great challenge of a revolving digital technology approach and management in agriculture value chain rehearsals and management through processing, packaging, and management in Nigeria. Primary and secondary data were used in this research, which aims at discovering appropriate measures to squarely or effectively address the problems in digital technology approach and management in agriculture value chain rehearsals and management through processing, packaging, storage, and distribution and/or marketing. Binary logistic regression and chi-square were also applied. The findings reveal that economic development along politics of social inclusion, democracy and rule of law has a nexus to addressing the complex nature of digital technology approach and management in (tulure value chain, processing, packaging, storage, distribution and/or marketing, of cooperative economics engagements practices, that addresses contemporary analysis of information system and technology management in business along global context motivations and innovations were used.

Keywords: Agriculture Value Chain, Mechanized Farming, Economics of Crop Processing, Inclusive/Economic Development, Packaging, Contemporary Analysis, and Marketing. storage, and distribution and/or marketing cannot be over-emphasized. This study 
failed. As a program the Vision 20-20-20 is targeted to making Nigeria one of the twenty largest world economies by the year 2020 - that would be a great miracle if it happens as we have just a few months to 2020; all government points agenda for the past three to four decades has been without food security in agriculture, functional education, wealth creation and employment, power and energy, and without human life or property security. The Gross Domestic Product (GDP) of Nigeria is made up of the following sectors; Agriculture, Industry, Building and Construction, Wholesale and Retail Trade and Services in the production sectors. Small Scale Enterprises (SSE) occupies a significant percentage of each sector of the GDP unit of Nigeria.

The higher GDP rate that Nigeria has in comparison to many countries of Africa is credited to the many efforts of small scale farmers who are committed to different agricultural production.

Nigeria seeks to become a leading economy in Africa and a major player in the economic and political affairs of the world. To become a developed nation, Nigeria needs to speed up its economic growth and development through focus on vital economic sectors like agriculture, education and manufacturing especially on the agriculture sector, power and energy. Nigeria has 75 percent of its land suitable for agriculture, but only $43 \%$ is cultivated, and which this research still rates to be $36.5 \%$ instead of $43 \%$. This is an indication that there is much room for the country to achieve much from land resources.

\section{Agriculture}

Agriculture is the growing and cultivation of crops, plants, animals, and other life forms for food, fiber, bio-fuel, medicinal and other products used to sustain and enhance human life. The study of agriculture is known as agricultural science. Economics of agriculture or agric economics including but not limited to economics of value chain in agriculture is concerned with the science or study of the science of how the advanced economic application handle all tools at both micro and macro levels to solve specific agriculture (or agricultural) problems in relations to production and consumption of all food items.

Agriculture was the key development in the rise of sedentary human civilization that established farming of domestic species of crops and created food supplies that nurtured the development of civilization and revolutions. Agriculture sector history dates back to six thousand years, and its development has been driven and defined by different climates, technologies, and cultures. All farming generally, relies however, on techniques to expand and maintain the lands that are suitable for raising domesticated species of farm resources. For plants, this usually requires some form of irrigation. Livestock are raised in a combination of grassland based and landless systems that takes place in industries that cover almost one-third of the world's ice-land and water free area.

Pre-industrial agriculture was typically subsistence agriculture, a self-sufficiency in which farmers grew most of their crops for their own consumption instead of commercial crop size for sale. The vast majority of the human population laboured in agriculture until the industrial revolution, and over the past century in response to new technologies and development of world markets, a remarkable shift in agriculture practices has occurred. This has led to technology improvements in agriculture techniques that made the traditional practice of recycling nutrients with crop rotation and animal manure less important to farmers. Industrial agriculture that is based on large scale monoculture is the dominant system of modern farming in the developed world of today, with growing support for 
sustainable agriculture, including organic agriculture and perma-culture. With food inflation soaring and disputes in many areas of the world or Africa, and Nigeria particularly, agriculture problems has been topical. We need to understand the relationships between labour and capital as is relevant to production functions at the micro level; and at the macro level, we need to collaborate the theory of excessive market power in the hands of supermarkets and the way governments decide how to give support to farmers especially without protection to the farmers.

\section{Objectives of the Study}

1. To ascertain the existing level of value chain on rice and cassava in Nigeria

2. To determine the effect of existing value chain in rice and cassava production in Nigeria

3. To provide necessary solutions to address the problems of agriculture value chain through processing, packaging, storage, distribution and/or marketing in Nigeria

\section{Research Questions}

1. What is the existing level of agriculture value chain in Nigeria?

2. What is the effect of existing agriculture value chain in Nigeria?

3. What is the solution to the problems of agriculture value chain in relation to processing, packaging, storage, distribution and/or marketing in Nigeria?

\section{Conceptual Clarification}

\section{Agriculture Value Chain Management}

The pre-industrial agriculture and modern mechanized agriculture have a nexus that interwove and addresses gre-areas of man and the necessities of life, and human health.

\section{Significance of the Study}

This study examines the contributions that a product value chain especially in the agriculture business (or agri-business) make to equitable growth, development (and employment) in societies and Nigeria in particular. While we have many real and viable products like: Rice, Yam, Cassava, Palm Oil, Cattle, Tomatoes, Cow peas, Maize, Millet, Cotton, Ground nuts, Bambara nuts, Edu, Sorghum value chain, etc. This research focuses or concentrates on "Rice" and "Cassava" value chain.

Rice

Rice, according to Nwele (2016), is one of the major cereal crops of the tropical regions of the world, and ranks first among the staple food crops in Nigeria. The text positions that rice production, processing, storage, and distribution is of significant importance especially to the federal government of Nigeria.

\section{Rice Production}

Economics of rice production involves creation of form utilities and wealth creation. The production process starts from seed or grain gathering to nursery or direct planting, transplantation (especially as in the case of tick or heavy 
swamps), nurturing (which include weeding or pesticide or fertilizer applications - '1st, 2nd, and maybe 3rd applications), harvesting, threshing, parboiling, milling, and bagging Nwele (1992).

\section{Cassava}

Cassava is one of the major cereal crops of the tropical regions of the world, and ranks third, after yam among the staple food crops in Nigeria.

\section{Cassava Production}

Economics of cassava production involves creation of form utilities and wealth creation. The production process starts from stem gathering to direct planting, nurturing (which include weeding or pesticide or fertilizer applications applications), harvesting, and further processing Nwele (1992).

\section{Value Chain}

Value Chain Marketing Groups shows value chain as tool or terms analysis that facilitates production processing in business activities in relation to new value adding opportunities, comparing existing values with regards to sourcing of factors of inputs, production, processing, packaging, and delivery and/or storage of finished products VCS (2014).

Fig.1 Rice Value Chain

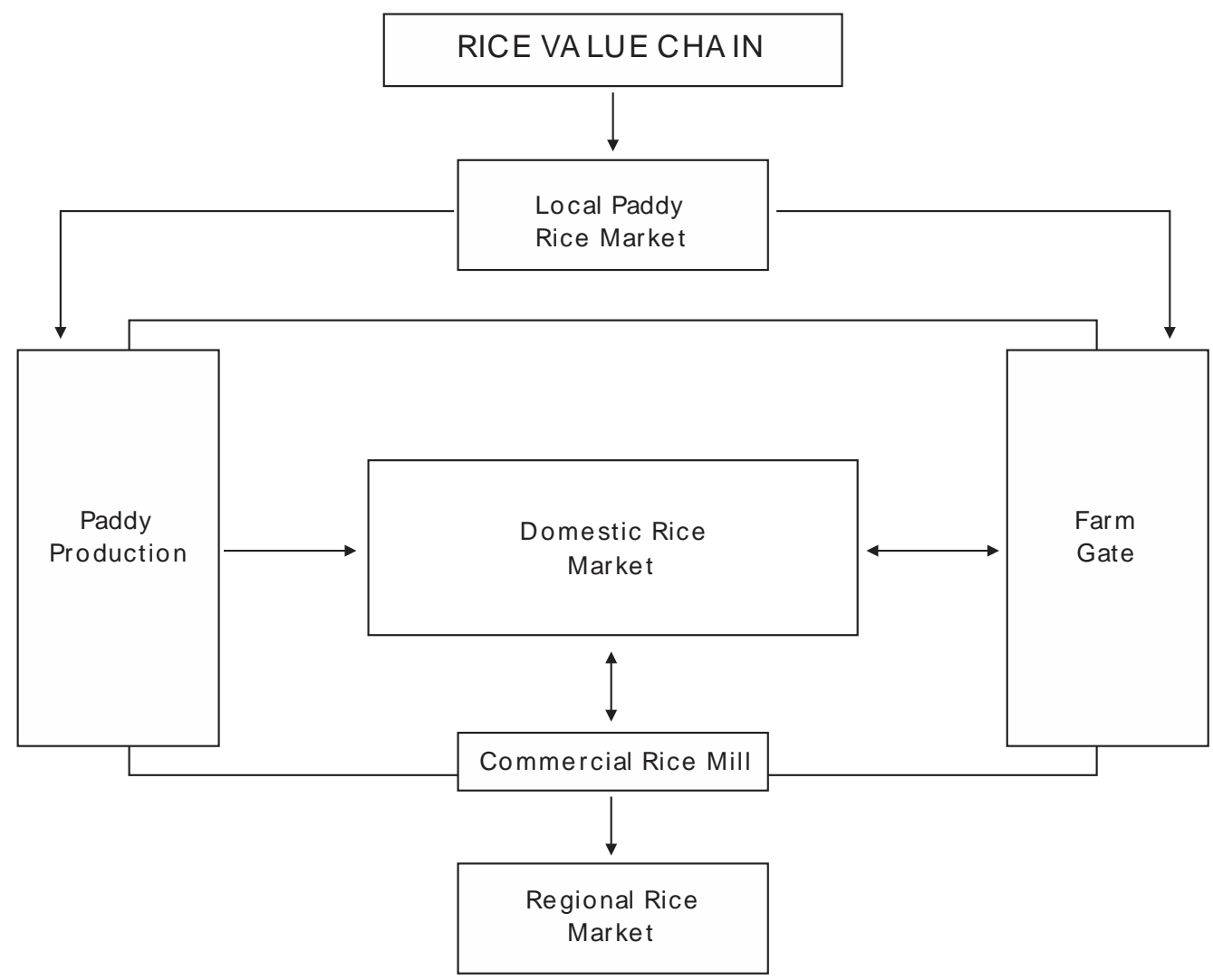

Source: Value Crest Stores (VCS), 2014 
Rice Value Chain

Rice value chain is a process term of new value addition in relation to existing values with regards to sources of factors inputs, production, processing, and delivery of the finished product Nwele (1992). Rice value chain covers areas of local paddy market, to the paddy production and the farm gate, cottage or industrial miller and mills, domestic and regional rice markets, then, the local buyer agents/consumers. Under the value chain are key drivers that encompass the 'stem' and chaffs that are used as animal feeds and as inorganic fertilizer/manure. The main rice seeds/grains are used and eaten as food - rice meal, 'fufu' or 'utaraeresh' or 'tuwoshinkafa.' Experiments are being made to ascertain the nature of the chemical content of the white fluid contained in rice produce. The value chain in rice produce is enormous. It creates employment at very high level. At the paddy markets you have buyers and sellers, at the farm gate you have skilled and unskilled labour, at the mills you have workforce. At the local and regional rice markets we have tripartite workforce of producers, agents and sellers, and buyers.

The charts below clearly identify the value chain attributes that accrues to both rice and cassava production in 'agriculture business value chain.'

Fig.2 Cassava Value Chain

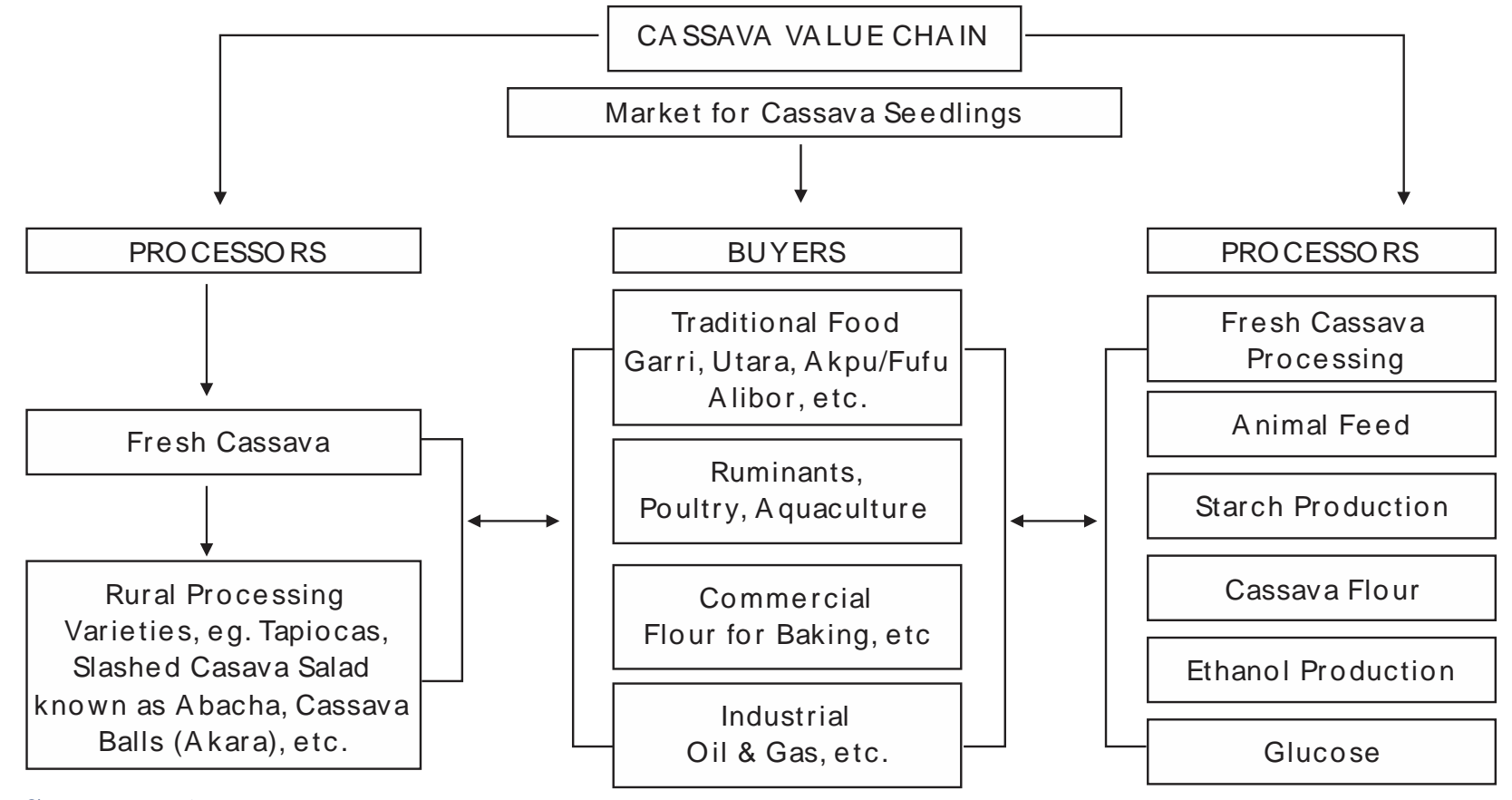

Source: Value Crest Stores (VCS), 2014

Value chain involves mapping the pattern of value-added distribution along the chain. The process involves measuring productivity and production capacity along profitability on cost, and comparing the performance of a business, value chain or value chain actor against competitors.

\section{Marketing Chains and Margins}

According to Nwele (2016), Marketing chains are part of marketing channel that describes the succession of markets through which products pass until they get to consumers. It reveals the relative importance of various 
market or exchange points in the marketing system. The margins represent the difference in price of a given product or commodity at different stages and as possession moves from the producer to the ultimate consumer.

\section{Review of Related Literature}

\section{Rice Production}

Rice is cultivated in almost all the agro-ecological zone in Nigeria. Despite this, the area cultivated still appears small. Looking at the past, in the year 2000 out of about 25 million hectares of land cultivated to various foods crops, only about $6.3 \%$ was cultivated to rice. During the period, the average national yield was 1.47 tons per hectare. Significant improvement in rice production in Nigeria occurred in 1980, when outputs increased to 1 million tons while cultivated land was 550 thousand hectares and yield was 1.9 tons per hectare. Throughout the 1980s rice output and yield increased, but in the 1990s, while rice output increased, the yield of rice declined, which suggests a problem on inputs of rice cultivated Nwele (2016)

Fig.3 Area Cultivated and Rice Output in Nigeria between 1961 and 2000

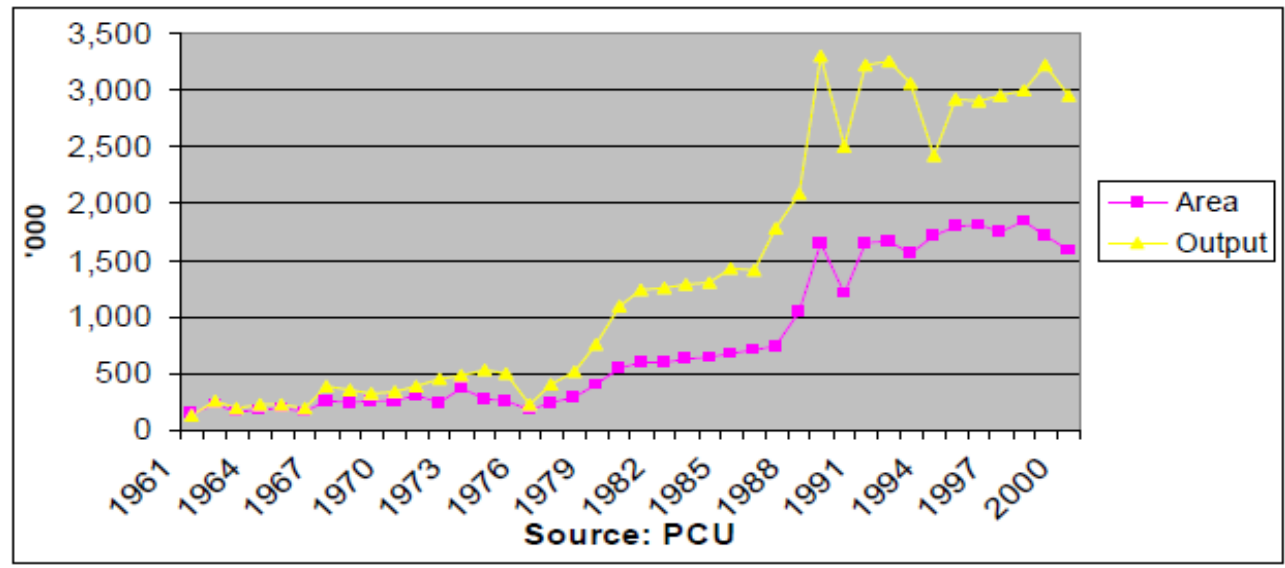

Source: PCU as copied from International Journal for Research in Business, Management and Accounting, Vol. 2 Issue 5 May 2016

Fig.4 Rice Yield in Nigeria between 1961 and 1999

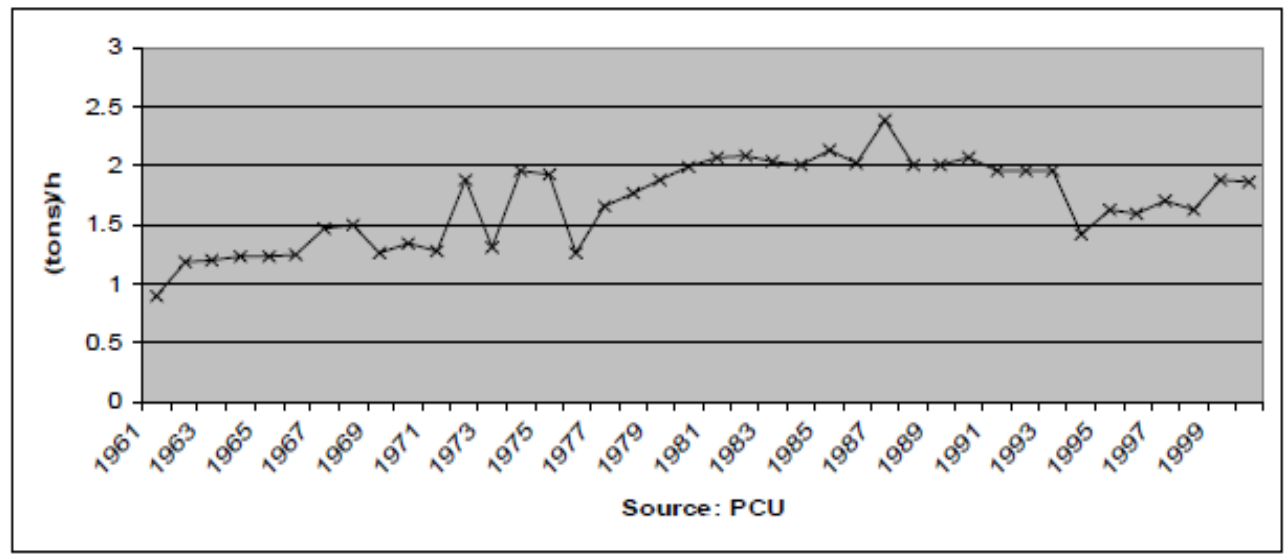

Source: PCU as copied from International Journal for Research in Business, Management and Accounting, Vol. 2 Issue 5 May 2016 
In the new agriculture arrangements or policy in Nigeria, rice and cassava have taken a large space in consideration for optimum production.

Fig. 5 Rice Yield in Nigeria between 1992 and 2016

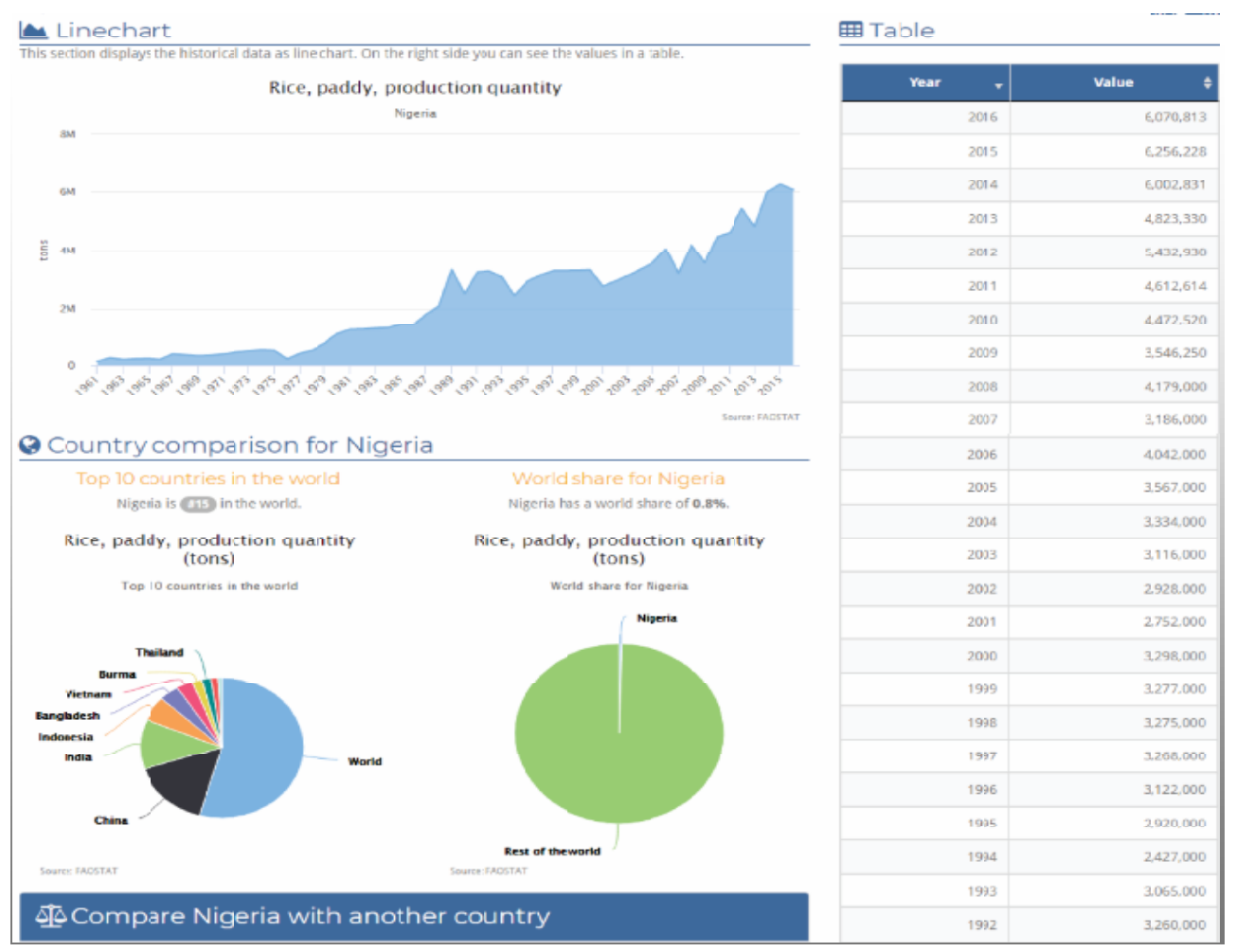

Source: http://www.factfish.com/statistic-country/nigeria/rice

Fig. 6 Cassava Yield in Nigeria between 1992 and 2016
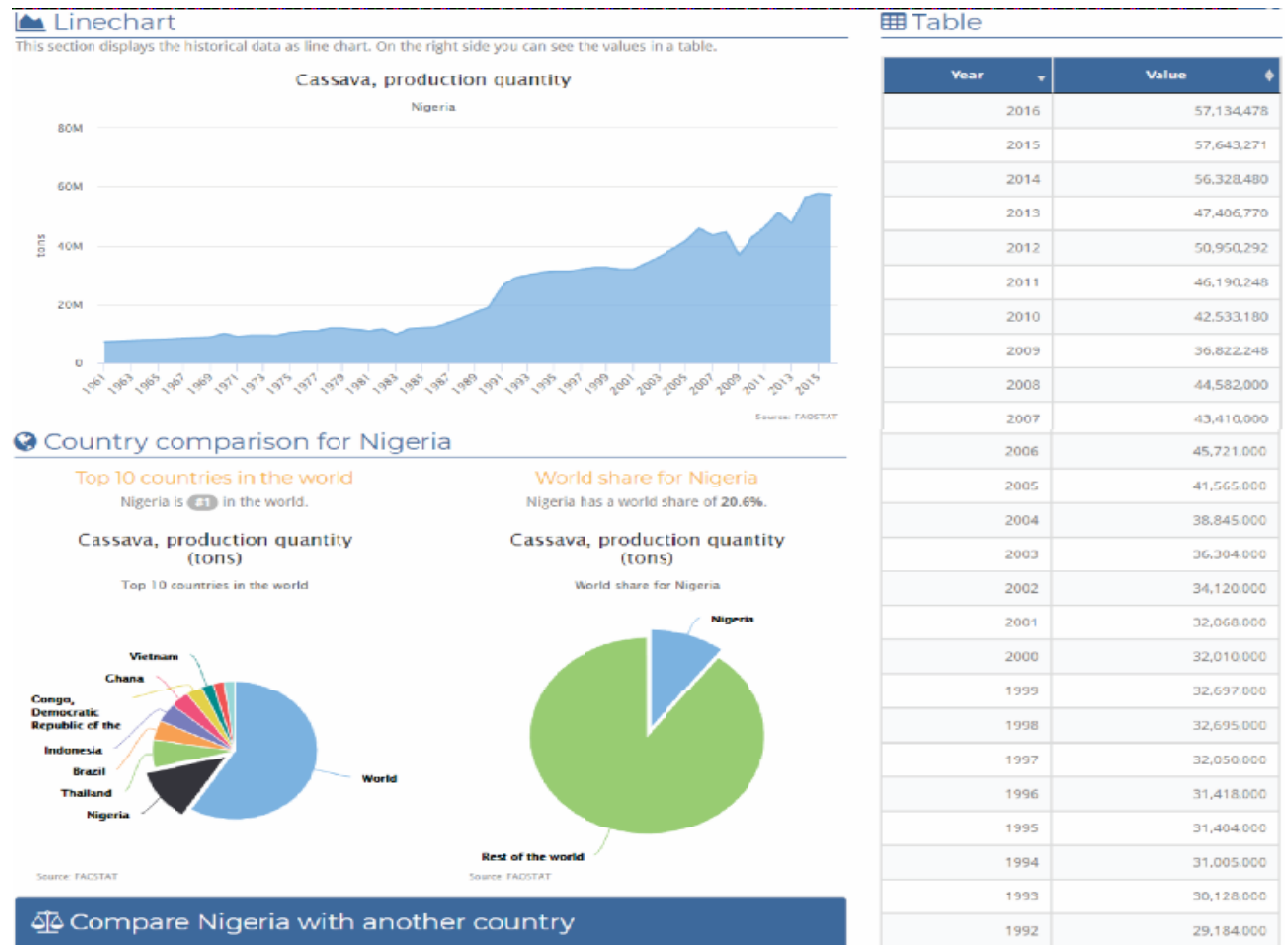

Source: http://www.factfish.com/statistic-country/nigeria/cassava 
Rice Production Prospects

The question one may want to ask is, how much more the government needs to allocate to agriculture expenditure to yield a certain amount of agricultural output in Nigeria; with a need to further investigate whether allocating such amount in an existing budget is justifiable or not.

Nigeria has an abundance of material and human resources and is fortunate to have an abundance of fertile soil along with a climate suitable for agriculture. There is also a supply of human resources that could benefit from having the agricultural sector to work in. Nigeria can join the league of economically developed nations by focusing on the improvement of its agricultural sector. A recent group study (Diao, Xinshen, Hazell, Peter \&Thurlow, 2009) examined the effect of other channels of growth on the decrease in poverty and the overall growth rate in six low-income countries of Africa. The findings of that research when applicable to Nigeria reflects the result, stating that industrial growth is less effective in reducing poverty than agricultural growth because a major percentage of the population (about 70\%) live in rural areas.

The agricultural sector is favourable as it allows greater employment opportunities for the poor. It was also noted by Diao et al that even though the industrial sector is important for boosting the economy, it fails to create sufficient employment opportunities for the poor and unskilled workers. In addition, the study stated that there was little evidence to prove that African countries could launch a successful economic transformation without going through an agricultural revolution on a country-wide basis.

\section{Agriculture and Nigerian Economy}

In the 1960s Nigeria's main domestic product was agriculture. This sector provided the country with employment and foreign exchange earnings. The agriculture sector never went away it was just overtaken by the oil boom that began in the 1970's (National Bureau of Statistics, 2012). The decline in output according to historical records, took place during the era of the oil boom which clearly indicates that the shift from rural to urban areas is responsible for the decrease in agricultural production. Agriculture being overtaken by oil the sector's impact on government and exports revenues is relatively small, accounting for only $4.8 \%$ of total foreign earnings and $24.4 \%$ of Gross Domestic Product (GDP) in 2016. The yield of most key crops such as cassava, cocoa beans, wheat, etc in Nigeria has declined and her share of global production for products such as palm oil, cocoa, groundnut and cassava remained low when compared to other countries that produce cassava, cocoa beans, oil palm and groundnut. For instance, in 2014, yields for cassava, cocoa beans, oil palm (fruit) and groundnuts were lower than the global average yield of all producing countries. This is possibly a reflection that unlike Nigeria with low utilization of improved seedlings and poor adoption of technology, other producing countries utilizes improved inputs and technology to increase their yield and production levels. In contrast to agriculture yield, agricultural land usage in Nigeria has increased across key crops like cassava, cocoa beans, rice paddy and wheat. The growth in usage has been primarily driven by an increase in population engaged in farming; however, production remains at subsistence level with resultant low productivity output. This invariably implies that in the long run, the use of technology and better inputs are expected to play an increasing role in raising agriculture productivity thereby reducing the growth of agricultural land usage. 


\section{Agriculture and Economic Development}

According to Nwele (2003), "Economic development leads to improvements in many sectors of a nation. There are a variety of indicators that economist use to measure the level of economic development of a country. These indicators include: declining poverty rates, increasing literacy rates, declining infant morbidity and increasing life expectancy. Economic development has to be supported by the whole nation from economists, politicians, and the people. Thus it can be concluded that, economic development leads to the creation of more opportunities in the sectors of education, health sector, human development, environmental conservation, and research, as it equally implies an increase in the per capita income of every citizen."

The country is divided into three main regions; the Eastern, Western and Northern regions. A study by Mona Crest Marketing Network and Value Crest Stores (2011) identified that the main problems of Nigeria stem from the fact that they are unable to access on 'progressive development order,' the natural and human resources as endowed by God. Also identified were the various factors that have an impact on the national agricultural production in Nigeria. They specifically examined the sectors of "crops, livestock, fishery and forest. The factors that were examined included population growth rate, GDP growth rate, consumer price index, food import values and the expenditure of government on the agricultural sector." Land, labour and machinery; which are equally important factors were as well analyzed. The study revealed that national agricultural production tends to decline whenever food import in the country increases. And that the major problem of increased participation on the part of farmers is lack of inclusive policy management of micro, small and medium credit facilities to real farmers MCMN \& VCS (2011)

\section{Market and Non-Market Forces}

Nigeria has been well known since its independence in 1960, for the significant amount of its exports of items like oil palm products, groundnuts and cocoa. At a time the federal government made a formal arrangement to market these exports internationally. These were known as marketing boards and given charge to handle the supply chain and logistics of these products after procuring them from the local farmers, for both local content management and export. Revenue was generated through the sales of the procured agricultural produce domestically and through exports. A widely accepted principle in economics states that "people respond to incentives" (Carbaugh, 2009). This connects to the impact of the existence of the marketing board as a chief incentive for key export commodity producers from the 1960s to the early 1980s. The main purpose of procuring, grading, marketing arrangements and export of these crops, was the development of the Nigerian agricultural export industry "for the benefit and prosperity of the producers."

\section{Theoretical Framework}

\section{Factors that affect Productivity in the Agricultural Sector}

The term 'growth' indicates an increase in a worker's productivity, or an increase in aggregate produce or income. Nigeria needs to understand what is required to compete favourably in the international market, and to grow, Nigeria should increase its productivity to determine how it can grow its productivity and how much it needs to grow to reach its target of becoming one of the next twenty developed economies by the end of 2020. Nigeria also 
needs to determine what it will require to achieve its target if it plans to concentrate mainly on agriculture for economic growth. To be successful, there needs to be a relation between agricultural output and the growth in GDP over a reasonable period, especially, on how to identify factors that are critical to agricultural development in the form of increase in output.

\section{Investment in Agriculture}

There is a dire need to allocate a sufficient amount of government spending on the agricultural sector in comparison to other sectors. The main problem faced by Nigeria's urban dwellers is a shortage of food supplies which results in excess importation. So to solve this problem, the Nigerian government should invest on a large-scale in subsidized production units through small scale finance support. Units like state farms and commercialized private farms should be in focus as the approach when implementing will result in a "trickle-down effect" of wealth from massive industrial projects to poor labour via employment. A small farmer can get subsidized inputs and has easy access to family labour and which helps him adapt to changes in costs. Getting more income from their own farms will allow farmers to live comfortably and reduce chances of rural emigration. Nigeria should now seriously put these plans into action to achieve income and food security and hence, economic development and growth.

\section{Estimation of Techniques}

This research used test of techniques that is based on the spot assessment of facts. A visit to some rice farms in Ebonyi State, Kano State, and Nassarawa State showed that farmers in Ebonyi State still uses much of manual labour and less of mechanized farming process in the production process of rice. Kano State uses more of mechanized than manual and Nassarawa State both as well.

\section{Discussion}

Significant degradation of land and water resources, including the depletion of aquifers, has been observed in recent decades, and the effects of global warming on agriculture and of agriculture on global warming are still not fully understood. Genetically modified organisms are ever increasing component of agriculture, although they are banned in some countries. Modern practices and selective breeding in animal husbandry have similarly increased the output of meat, but have raised concerns about animal welfare and the health effects of the growth hormones, antibiotics, and other chemicals commonly used in industrial meat production.

Agronomy of the modern world, plant breeding, agrochemicals such as fertilizers and pesticides, and technological improvements have sharply increased yields from cultivation, but at the same time have caused widespread ecological damage and negative human health effects.

\section{The relationship between small scale agriculture and wealth creation}

Defining who is a small scale producer or processor is not easy. Some arbitrary income figure like the number of hectares owned or number of employees, or amount of livestock raised, comes to mind in describing the small scale food sector using terms such as local, specialty, artisanal and direct marketing. Small scale producers tend to have a limited land base, raise multiple types of crops, or livestock, practice integrated farming methods and market their products directly, either from the farm or through a farmers' market or cooperatives. There are also a number of 
larger, conventional farms that dedicate a portion of their farm to specialized, local food production - in effect, a small scale operation. Small scale food processors also typically have few employees, produce a limited number of specialty products and market their products either directly or through outlets that focus on local foods.

Small scale enterprises do survive and many small scale food processors have indicated marketing as one of their biggest hurdles. They have argued that it was difficult for them to access modern distribution chains and retail grocery stores. On the other hand, most small scale farmers who marketed directly to the consumer had little difficulty in selling their products. Most institutions and restaurants who purchased local foods directly had established their own network of suppliers with several local food distributors who operate in the intermediary marketing.

Nigeria wishes to become one of the twenty largest world economies by the year 2020 according to its vision 20-20-20 program. The country being rich in natural resources should focus on developing its agricultural sector as an essential strategic move to progress its economy. Nigeria should use import substitution to protect domestic farmers and after the local food requirements are fulfilled, it should export surplus production. Value addition would help the country earn more from exports.

Currently Nigeria can either invest in large-scale production units or develop a program to provide subsidized key inputs to small scale agriculture. Being an agro-based economy will help Nigeria ensure food security and a consistent income for small scale farmers and it will help the country pull itself out of debt and poverty. It has also been discussed and established that Nigeria has the natural and human resources necessary to have a strong agriculture sector. Agriculture used to be the main source of revenue for the country, so it is known that the climate and soil are conducive to agriculture. It has as well been fully demonstrated that it is plausible for Nigeria to diversify into the agriculture market in their effort to become more self-sustainable and a world economic power.

\section{Findings of the Study}

1. The research findings reveals that there is existing level of agriculture value chain in Nigeria

2. That the existing agriculture value chain has significant effect on food supply in Nigeria

3. That the solution to the problems of agriculture value chain in relation to processing, packaging, storage, distribution and/or marketing in Nigeria lies on government policy initiatives that will impact on the people and the farmers too.

\section{Conclusion}

1. From the research findings the existing level of agriculture value chain in Nigeria is not sufficient compared to development indices currently available and in-view.

2. The existing agriculture value chain should be significantly increased to provide for model growth and development.

3. The solution to the problems of agriculture value chain in relation to processing, packaging, storage, distribution and/or marketing in Nigeria lies on government policy initiatives that will impact on the people and 
the farmers too. To channel itself on the path to modern development, Nigeria should examine what factors hindered the development of its agricultural sector, which was the backbone of the Nigerian economy before the era of oil boom.

To channel itself on the path to modern development, Nigeria should examine what factors hindered the development of its agricultural sector, which was the backbone of the Nigerian economy before the era of oil boom. Focus on rice and cassava value chain in production is paramount. To rectify the mistakes Nigeria made in the last fifty years by immediately putting strategic plans into action. The people of Nigeria can uplift themselves from poverty and by distress, eradicating corruption and devoting themselves to the commitment of striving for progress. The 20-20-20 initiative will keep Nigeria focused on improving the economy with a significant effort to reduce food imports and to increase food production within the country. Nigeria can see a timely turn around in agricultural investment, as Nigeria has the necessary components in place to return to an agricultural-based economy. Research has demonstrated that a return to an agricultural economy is not only possible, but will greatly benefit the entire Nigeria.

\section{Recommendations}

As a result of the researchers various findings as enumerated, the following recommendations are hereby suggested:

1) That Nigeria's government, considering all that has been discussed, through this research on researchers theoretical analysis, the review of related literature and research findings obtained in this study, should re-examine the existing level of agriculture value chain.

2) That government needs to increase significantly, the level of agriculture value chain available, to impact favourably on the population.

3) That Nigeria's government, considering all that has been discussed, through this research on the researcher's theoretical analysis, the review of related literature and research findings obtained in this study, should review her policy on agriculture, to provide for equity and fair play, to all real rice, and cassava farmers.

There is a dire need to allocate sufficient amount of government spending on the agricultural sector in comparison to other sectors. The main problem faced by Nigeria's urban dwellers is a shortage of food supplies which results in excess importation. So to solve the problem, the researchers recommend that government should invest on a large-scale in subsidized production units through small scale finance support. Small farmer should be encouraged to get subsidized inputs and have easy access to labour that helps him/her to adapt to changes in costs. Getting more income from their own farms will allow farmers to live comfortably and reduce chances of rural emigration. Nigeria should now seriously put these plans to prudent actions to achieve income and food security and hence, economic growth and development. 
Mona Crest Marketing Network, Enugu (2011), A study identifying the main problems of Nigeria in agriculture, access to natural and human resources; a 2011 survey.

National Bureau of Statistics. Agriculture (2012)

Retrieved January 27, 2014, from http://www.nigerianstat.gov.ng/sectorstat/sectors/Agriculture

Nwele J.O. (1992), "Rice Production for Economic Growth and Development through Agri-Business Projects," an unpublished paper of a Youth Training in Agriculture, Abbaomege, 1992

Nwele J.O. (2003), "Economic Growth and Development through Agri-Business Projects, an unpublished paper of a UNDP Programme on Training the Trainers' ... Bauchi 2003

Nwele J.O. (2016), “Economics of Rice Production and Marketing in Nigeria: A Study of Ebonyi State, published by International Journal for Research I Business, Management and Accounting; Vol. 2 Issue 5, May 2016

Todaro, P. M., \& Smith, C. S. (2006); "Economic development (9th ed.), Boston, MA: Pearson Addison Wesley." Value Crest Stores (VCS), 2014 an unpublished Marketing Research Report, used for product marketing analysis, and class work for Seminar Projects, 2014.

http://www.factfish.com/statistic-country/nigeria/rice

http://www.factfish.com/statistic-country/nigeria/cassava 